\title{
Adiponectin, leptin, and resistin in patients with aortic stenosis without concomitant atherosclerotic vascular disease
}

\author{
Renata Kolasa-Trela', Tomasz Miszalski-Jamka', \\ Grzegorz Grudzień ${ }^{1,2}$, Ewa Wypasek ${ }^{1,2}$, Magdalena Kostkiewicz ${ }^{1,2}$ \\ 1 John Paul II Hospital, Kraków, Poland \\ 2 Institute of Cardiology, Jagiellonian University, Medical College, Kraków, Poland
}

\section{KEY WORDS}

adipocytokines, adiponectin, aortic stenosis, leptin, resistin
Correspondence to:

Magdalena Kostkiewicz, MD, PhD, Instytut Kardiologii, Uniwersytet Jagielloński, Collegium Medicum, ul. Prądnicka 80, 31-202 Kraków, Poland, phone: +48-12-614-35-14, fax: +48-12-614-25-26, e-mail: mkostkiewicz@szpitaljp2.krakow.pl Received: September 2, 2011 Revision accepted: September 23, 2011. Conflict of interest: none declared. Pol Arch Med Wewn. 2011; 121 (10): 352-360 Copyright by Medycyna Praktyczna, Kraków 2011

\section{ABSTRACT}

INTRODUCTION Early stages of atherosclerosis and aortic stenosis (AS) are similar. Advanced coronary artery disease is characterized by altered profile of circulating adipocytokines. We hypothesized that plasma profile of adipocytokines is associated with the severity of AS.

OBJECTIVES The aim of the study was to evaluate the relationship between AS and adipocytokines. PATIENTS AND METHODS In 74 patients with AS without atherosclerosis and left ventricular ejection fraction above $50 \%$ (57 men, 17 women, aged $58 \pm 9.1$ years) and 74 controls, resistin, leptin, and adiponectin levels were determined by the Bio-Rad Luminex system. Aortic valve area indexed to body surface area (AVAl) as well as the mean and peak transvalvular pressure gradients (PG) were assessed by echocardiography.

RESULTS We observed similar adiponectin and leptin levels in patients with AS and controls (20.8 \pm 7.9 vs. $20.4 \pm 3.9 \mu \mathrm{g} / \mathrm{ml}, P=0.67$ and $17.0 \pm 6.4$ vs. $16.4 \pm 5.9 \mathrm{ng} / \mathrm{ml}, P=0.52$, respectively). Twenty-one patients had mild, 21 moderate, and 32 severe AS. After adjusting for age and the body mass index, adiponectin levels were $20.3 \pm 0.5 \mu \mathrm{g} / \mathrm{ml}$ in controls, $26.7 \pm 0.9 \mu \mathrm{g} / \mathrm{ml}$ in mild, $20.2 \pm 0.9 \mu \mathrm{g} / \mathrm{ml}$ in moderate, and $17.5 \pm 0.7 \mu \mathrm{g} / \mathrm{ml}$ in severe AS $(P<0.001)$. Leptin levels were $16.4 \pm 0.7 \mathrm{ng} / \mathrm{ml}$ in controls, $21.1 \pm 1.3 \mathrm{ng} / \mathrm{ml}$ in mild, $16.9 \pm 1.3 \mathrm{ng} / \mathrm{ml}$ in moderate, and $14.4 \pm 1.1 \mathrm{ng} / \mathrm{ml}$ in severe AS $(P=0.003)$. Adiponectin and leptin correlated with the AVAl $(r=0.70, P<0.001 ; r=0.37, P=0.001$; respectively), mean PG $(r=-0.72, P<0.001 ; r=-0.27, P=0.009$; respectively), and peak $P G(r=-0.67, P<0.001$; $r=-0.23, P=0.03$; respectively). In a multivariable analysis, the mean $P G$ was the only independent echocardiographic predictor of adiponectin levels $(P<0.001)$, while the AVAl was the only independent echocardiographic predictor of leptin levels in AS patients $(P=0.049)$.

CONCLUSIONS Lower levels of adiponectin and leptin, but not resistin, are associated with severe AS, suggesting that adipocytokines may be involved in the progression of AS, and especially adiponectin, which plays a protective role in this process.

INTRODUCTION Aortic stenosis (AS) is the most common valvular heart disease in adults, with the highest prevalence among elderly patients. Aortic valvular lesions have some similarities to atherosclerosis including chronic inflammation, the presence of lipoproteins, cholesterol, macrophages, T cells, ${ }^{1}$ and calcification. ${ }^{2}$ Growing evidence indicates that $\mathrm{AS}$ is an active, potentially modifiable inflammatory process.

In contrast to multiple cytokines involved in the development of AS, adipocytokines in AS have attracted less interest despite their role in atherosclerosis. Adiponectin, leptin, and resistin play a major role in glucose metabolism, insulin 
resistance, and inflammatory state associated with adipose tissue dysfunction. ${ }^{3}$ Visceral adiposity contributes to chronic subclinical inflammation with infiltration of $\mathrm{T}$ cells and macrophages, both associated with systemic vascular dysfunction and insulin resistance in obese subjects. ${ }^{4}$

Adiponectin is considered to be an antiatherosclerotic and cardioprotective cytokine. ${ }^{5} \mathrm{Ad}-$ iponectin releases nitric oxide, modulates macrophage function, and inhibits the production of tumor necrosis factor $\alpha$ and interleukin (IL) $6 .{ }^{6} \mathrm{It}$ stimulates the synthesis of anti-inflammatory cytokines such as IL-10 and IL-1 $\beta .{ }^{6}$ Plasma adiponectin levels are reduced in obese, insulin-resistant, or dyslipidemic subjects. ${ }^{7}$ Shibata et al. $^{8}$ demonstrated the cardioprotective action of adiponectin in patients after myocardial infarction (MI) by inhibiting myocardial hypertrophy and interstitial fibrosis. ${ }^{8}$ However, not all studies have confirmed the inhibitory effect of adiponectin on myocardial hypertrophy and fibrosis. ${ }^{9}$ Moreover, a protective role of adiponectin in the vascular calcification has been demonstrated in a mouse model. ${ }^{10}$

Leptin is a proatherogenic hormone. It stimulates platelet activity and smooth muscle cell proliferation and induces oxidative stress and endothelial dysfunction. ${ }^{11}$ Hyperleptinemia may contribute to an increased cardiovascular morbidity $^{12}$ and a higher risk of arterial hypertension. ${ }^{13}$ Serum leptin levels are significantly higher in patients with chronic stable angina and ST-elevated MI. ${ }^{14}$ Leptin has been shown to have both vasoconstricting and relaxing properties. ${ }^{15}$ It is also involved in myocardial hypertrophy ${ }^{16}$ and the regulation of cardiac contraction. ${ }^{17}$ Moreover, leptin has been associated with a reduction in cardiac lipid accumulation ${ }^{18}$ and protection against ischemia-reperfusion injury. ${ }^{19}$

Resistin has proinflammatory properties. It induces the release of proinflammatory markers from endothelial cells (endothelin-1) and the production of vascular cell adhesion molecule $1 .{ }^{12}$ In rodents, the main action of resistin is to impair insulin sensitivity. ${ }^{20}$ Mice deficient in resistin are protected against obesity. However, the role of resistin in humans remains unclear. Plasma resistin levels have been shown to correlate with inflammation, but not with insulin resistance, and they may predict coronary atherosclerosis. ${ }^{21}$ Of note, Monthy et $\mathrm{al}^{22}$ have demonstrated that higher plasma resistin levels are associated with the extent of valvular calcification and inflammation in elderly patients with AS.

Since atherosclerosis, metabolic syndrome, and AS are considered as chronic inflammation, we hypothesized that adipocytokines, which participate in inflammation and cardiac hypertrophy and remodeling, might be implicated in the progression of AS. Therefore, the aim of our study was to assess the association between these cytokines and the severity of AS.

PATIENTS AND METHODS We studied consecutive patients with AS, who were scheduled for transthoracic echocardiography (TTE). Subjects with a concomitant valvular disease in the form of only mild-to-moderate aortic/mitral/tricus$\mathrm{pid} /$ pulmonary regurgitation without mitral/ tricuspid/pulmonary stenosis were eligible. $\mathrm{Pa}$ tients with decreased left ventricular (LV) contractility, defined as LV ejection fraction (LVEF) below 50\%, known or suspected coronary artery disease, carotid artery stenosis or ischemic stroke, diagnosed type 2 diabetes, atrial fibrillation at the time of TTE, and suboptimal image quality were excluded. Sex- and age-matched individuals recruited from the hospital personnel served as controls. The University Ethical Committee approved the study; and the patients provided written informed consent.

Data concerning demographics, cardiovascular risk factors, and current treatment were collected from all participants using a standardized questionnaire. Patients were classified as having arterial hypertension if they met one of the following criteria: 1) diagnosis of hypertension in medical history; 2) antihypertensive treatment before admission; 3) systolic or diastolic pressure $\geq 140 \mathrm{mmHg}$ or $\geq 90 \mathrm{mmHg}$, respectively, on at least 2 different occasions. Diabetes was defined as a history of diabetes, regardless of the duration of the disease or treatment with hypoglycemic agents. Current smoking was defined as smoking at least 5 cigarettes a day.

Echocardiography TTE was performed using the Vivid 7 ultrasound device (GE Vingmed Ultrasound $\mathrm{A} / \mathrm{S}$, Horten, Norway). In each patient, M-mode and two-dimensional echocardiograms were obtained, followed by pulsed and continuous-wave Doppler ultrasound. Conventional techniques were used for measurement of LVEF and end-diastolic volume, which was indexed to body surface area. Aortic valve area indexed to body surface area (AVAI) was calculated using the standard continuity equation. Transvalvular pressure gradients (PG) were measured by Doppler echocardiography using the modified Bernoulli equation.

Laboratory parameters Fasting blood samples were drawn from an antecubital vein with minimal stasis at 8 to 10 a.m. Lipid profiles, blood cell count, glucose, and creatinine were assayed by routine laboratory techniques. Blood samples (vol/vol, 9:1 of 3.2\% trisodium citrate) were centrifuged at $2560 \mathrm{~g}$ for 20 minutes; the supernatant was aliquoted and stored at $-80^{\circ} \mathrm{C}$. Fibrinogen was determined using the Clauss method. High-sensitivity $C$-reactive protein was measured by nephelometry (Dade Behring, Marburg, Germany). Adiponectin, leptin, and resistin were measured in plasma using the Bio-Rad Luminex system (Millepore, Billerica, Massachusetts, United States). Coefficients of variation for the 3 analytes ranged from $6.5 \%$ to $10 \%$. 
TABLE 1 Patient characteristics

\begin{tabular}{|c|c|c|c|c|c|c|c|}
\hline & $\begin{array}{c}\text { AS patients } \\
\mathrm{n}=74\end{array}$ & $\begin{array}{c}\text { Controls } \\
n=74\end{array}$ & $P$ a & $\begin{array}{l}\text { Mild AS } \\
n=21\end{array}$ & $\begin{array}{c}\text { Moderate AS } \\
n=21\end{array}$ & $\begin{array}{c}\text { Severe AS } \\
n=32\end{array}$ & $P^{\mathrm{b}}$ \\
\hline male sex, n (\%) & $57(77)$ & $57(77)$ & 1.0 & $14(67)$ & $16(76)$ & $27(84)$ & 0.32 \\
\hline age, y & $58.0 \pm 9.1$ & $57.7 \pm 9.2$ & 0.84 & $65.3 \pm 9.7$ & $58.0 \pm 7.7$ & $53.3 \pm 6.1$ & $<0.001$ \\
\hline $\mathrm{BMI}, \mathrm{kg} / \mathrm{m}^{2}$ & $28.0 \pm 3.5$ & $27.8 \pm 3.1$ & 0.68 & $26.7 \pm 4.0$ & $28.3 \pm 3.2$ & $28.7 \pm 3.3$ & 0.13 \\
\hline smoking, $\mathrm{n}(\%)$ & $30(41)$ & $22(30)$ & 0.23 & $6(29)$ & $11(52)$ & $13(41)$ & 0.29 \\
\hline arterial hypertension, $\mathrm{n}(\%)$ & $45(61)$ & $40(55)$ & 0.51 & $13(62)$ & $10(48)$ & $22(69)$ & 0.31 \\
\hline hypercholesterolemia, n (\%) & $66(89)$ & $25(34)$ & $<0.0001$ & $20(95)$ & $20(95)$ & $26(81)$ & 0.16 \\
\hline \multicolumn{8}{|l|}{ laboratory parameters } \\
\hline fasting glucose, $\mathrm{mmol} / \mathrm{l}$ & $5.4 \pm 0.1$ & $5.0 \pm 0.1$ & $<0.001$ & $5.3 \pm 0.1$ & $5.4 \pm 0.1$ & $5.6 \pm 0.1$ & $<0.001$ \\
\hline $\mathrm{TC}, \mathrm{mmol} / \mathrm{l}$ & $5.0 \pm 0.1$ & $4.8 \pm 0.1$ & 0.18 & $5.2 \pm 0.2$ & $5.4 \pm 0.2$ & $4.7 \pm 0.2$ & 0.03 \\
\hline LDL-C, mmol/l & $3.0 \pm 0.1$ & $2.8 \pm 0.1$ & 0.10 & $3.3 \pm 0.1$ & $3.2 \pm 0.2$ & $2.7 \pm 1.3$ & 0.048 \\
\hline $\mathrm{HDL}-\mathrm{C}, \mathrm{mmol} / \mathrm{l}$ & $1.2 \pm 0.03$ & $1.4 \pm 0.03$ & $<0.001$ & $1.2 \pm 0.06$ & $1.2 \pm 0.06$ & $1.2 \pm 0.05$ & $<0.001$ \\
\hline $\mathrm{TG}, \mathrm{mmol} / \mathrm{l}$ & $1.7 \pm 0.1$ & $1.3 \pm 0.1$ & 0.007 & $1.4 \pm 0.2$ & $1.9 \pm 0.2$ & $1.7 \pm 0.2$ & 0.02 \\
\hline creatinine, $\mu \mathrm{mol} / \mathrm{l}$ & $85.6 \pm 1.5$ & $77.3 \pm 1.5$ & $<0.001$ & $86.5 \pm 3.1$ & $87.5 \pm 2.9$ & $83.7 \pm 2.4$ & 0.002 \\
\hline hsCRP, mg/l & $3.3 \pm 0.2$ & $1.5 \pm 0.2$ & $<0.001$ & $3.1 \pm 0.3$ & $4.0 \pm 0.3$ & $3.0 \pm 0.3$ & $<0.001$ \\
\hline fibrinogen, $g / l$ & $4.5 \pm 0.1$ & $2.7 \pm 0.1$ & $<0.001$ & $4.5 \pm 0.2$ & $4.4 \pm 0.2$ & $4.6 \pm 0.2$ & $<0.001$ \\
\hline
\end{tabular}

a $P$ value refers to comparisons between all AS patients and controls

b $P$ value refers to comparisons between patients with mild, moderate, and severe AS

Continuous data are presented as mean \pm SD and categorical data as number (\%); laboratory data were adjusted for age and BMI.

Abbreviations: AS - aortic stenosis, BMI - body mass index, HDL-C - high-density lipoprotein cholesterol, hsCRP - high-sensitivity C-reactive protein, LDL-C - low-density lipoprotein cholesterol, SD - standard deviation, TC - total cholesterol, TG - triglycerides

Statistical analysis Continuous data are presented as a mean \pm standard deviation and categorical data as prevalence (\%). The Kolmogorov-Smirnov test was performed to assess conformity with normal distribution. Unpaired categorical variables were compared by the Fisher exact test or $\chi^{2}$ test as appropriate. The $t$ test and one-way analysis of variance (ANOVA) were applied to determine differences between continuous variables. A linear regression analysis was used to correlate variables. An analysis of covariance was performed to eliminate the confounding effect of age and the body mass index (BMI) on tested variables among patients with different AS severity. The ANOVA with

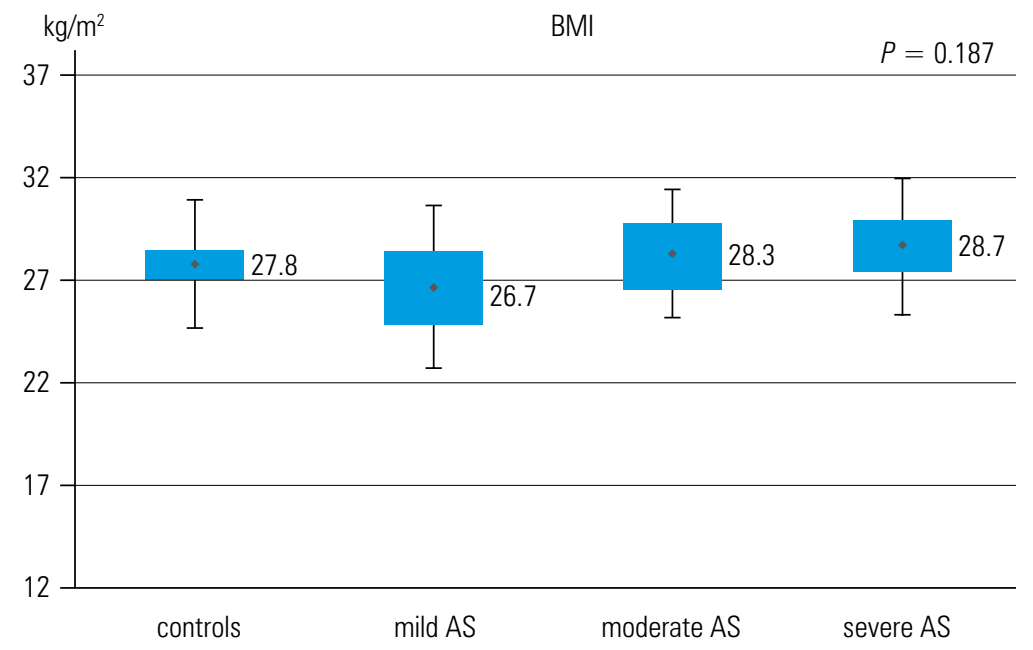

FIGURE 1 Body mass index in patients with aortic stenosis and in controls; values are shown as mean \pm SD and $95 \% \mathrm{Cl}$

Abbreviations: $\mathrm{Cl}$ - confidence interval, others - see TABLE 1 post-hoc Sidak tests was performed to assess differences between groups. A multiple linear regression analysis was performed in a two-step sequential model to determine incremental value of echocardiographic (second step) over clinical (first step) predictors for adiponectin, leptin, and resistin. The clinical and echocardiographic variables, which demonstrated associations in the initial linear regression analysis, were included into the sequential models. The incremental prognostic value was defined by a significant increase in the global $\chi^{2}$. The presented data represent the best-fit model as determined by $\mathrm{R}^{2}$ value. A univariable-logistic regression analysis was performed to determine potential predictors of severe AS among clinical, laboratory, and echocardiographic data. Afterwards, a multivariable logistic regression of these potential predictors was performed in a stepwise forward fashion to identify parameters associated with severe AS. The odds ratio (OR) with the corresponding 95\% confidence interval (CI) was calculated for each parameter. Entry was set at $P<0.05$, while retention at $P<0.10$. $P<0.05$ was considered statistically significant. Statistical analysis was performed using the SPSS software (version 12.0, SPSS Inc., Chicago, IL, United States).

RESULTS Clinical data Of 83 screened subjects, 74 patients with AS were included in the final analysis (57 men, 17 women, mean age $58 \pm 9.1$ years). Three patients were excluded due to inadequate quality of echocardiographic image $(n=3)$. Patient characteristics are summarized in TABLE 1. Distribution of the BMI in patients with various 
TABLE 2 Echocardiographic parameters

\begin{tabular}{llllll} 
Variable & AS patients $(n=74)$ & Mild AS $(n=21)$ & Moderate AS $(n=21)$ & Severe AS $(n=32)$ & $P$ \\
LVEF, $\%$ & $62.5 \pm 8.0$ & $62.7 \pm 8.0$ & $59.6 \pm 7.0$ & $64.1 \pm 8.4$ & 0.13 \\
\hline LVEDV index, $\mathrm{ml} / \mathrm{m}^{2}$ & $73.2 \pm 19.5$ & $77.8 \pm 19.1$ & $72.6 \pm 5.5$ & $70.6 \pm 15.2$ & 0.42 \\
\hline mean pressure gradient, $\mathrm{mmHg}$ & $50.1 \pm 19.7$ & $29.4 \pm 12.1$ & $49.8 \pm 14.0$ & $64.0 \pm 14.2$ & $<0.001$ \\
\hline peak pressure gradient, $\mathrm{mmHg}$ & $74.8 \pm 21.6$ & $52.7 \pm 15.3$ & $74.6 \pm 16.0$ & $89.5 \pm 15.1$ & $<0.001$ \\
\hline bicuspid aortic valve, $\mathrm{n}(\%)$ & $15(20)$ & $1(5)$ & $4(19)$ & $10(31)$ & $0.5 \pm 0.1$ \\
\hline AVAl, $\mathrm{cm}^{2} / \mathrm{m}^{2}$ & $0.8 \pm 0.3$ & $1.2 \pm 0.2$ & $0.8 \pm 0.1$ & $13.6 \pm 0.8$ & $<0.001$ \\
\hline intraventricular septum, $\mathrm{mm}$ & $12.8 \pm 1.3$ & $11.8 \pm 1.4$ & $12.8 \pm 1.1$ & $14.1 \pm 1.1$ & $<0.001$ \\
\hline posterior wall, $\mathrm{mm}$ & $13.4 \pm 1.7$ & $11.9 \pm 1.6$ & $13.8 \pm 1.7$ & $<0.001$ \\
\hline
\end{tabular}

Abbreviations: AVAI - aortic valve area index, LVEDV - left ventricular end diastolic volume, LVEF - left ventricular ejection fraction, others - see TABLE 1

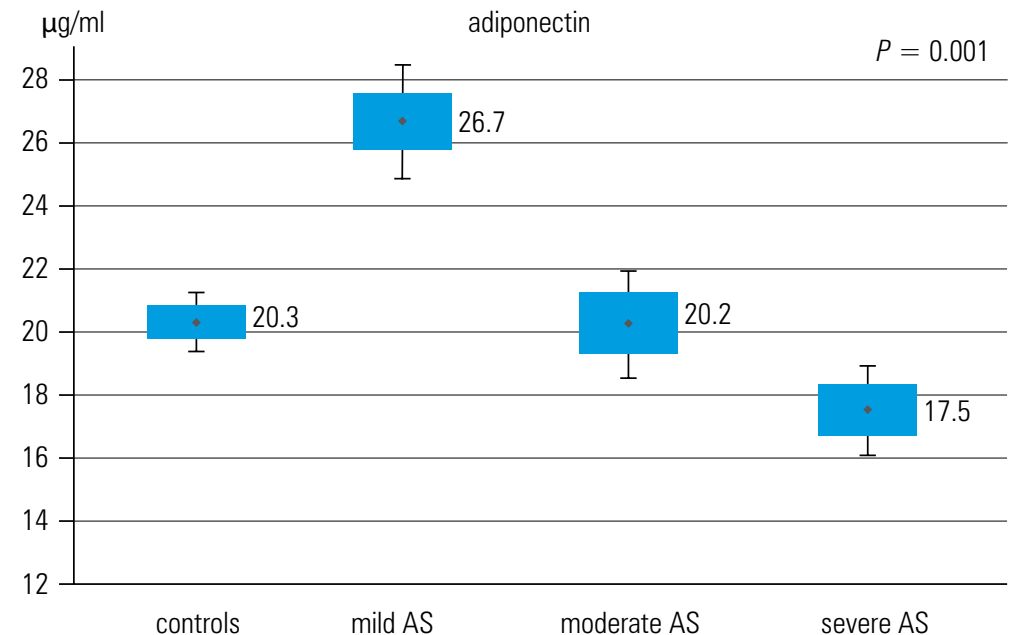

post-hoc analysis:

controls vs. mild AS $(P<0.001)$, moderate AS $(P=0.999)$, severe AS $(P=0.005)$ mild AS vs. moderate AS $(P<0.001)$, severe AS $(P<0.001)$ moderate AS vs. severe AS $(P=0.092)$

FIGURE 2 Plasma levels of adiponectin in patients with aortic stenosis and in controls: values are shown as mean \pm SD and $95 \% \mathrm{Cl}$

Abbreviations: see TABLE 1 and FIGURE 1

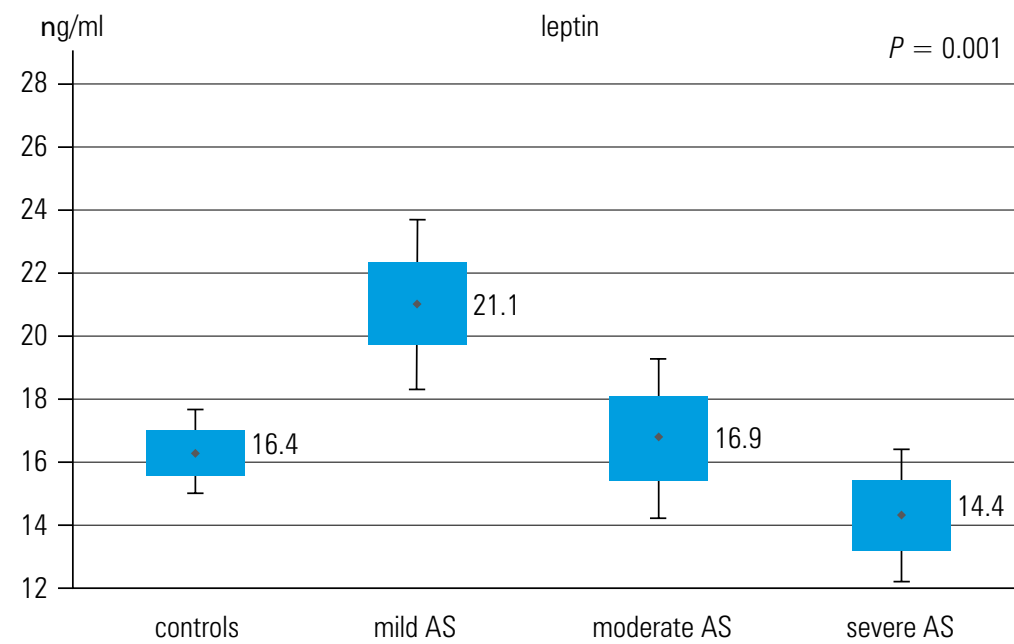

post-hoc analysis:

controls vs. mild AS $(P<0.014)$, moderate AS $(P=0.999)$, severe AS $(P=0.505)$ mild AS vs. moderate AS $(P<0.13)$, severe AS $(P<0.001)$ moderate AS vs. severe AS $(P=0.607)$

FIGURE 3 Plasma levels of leptin in patients with aortic stenosis and in controls; values are shown as mean $\pm \mathrm{SD}$ and $95 \% \mathrm{Cl}$ Abbreviations: see TABLE 1 and FIGURE 1 levels of AS severity and in controls is presented in FIGURE 1. We observed similar adiponectin and leptin levels in patients with AS and controls $(20.8 \pm 7.9$ vs. $20.4 \pm 3.9 \mu \mathrm{g} / \mathrm{ml}, P=0.67$ and 17.0 \pm 6.4 vs. $16.4 \pm 5.9 \mathrm{ng} / \mathrm{ml}, P=0.52$, respectively). In patients with $\mathrm{AS}$, adiponectin showed a strong correlation with age $(r=0.80, P<0.001)$ and moderate with BMI $(r=-0.50, P<0.001)$. Similar, though weaker, correlations were observed for leptin $(r=0.33, P=0.002$ and $r=-0.37, P=$ 0.001 , respectively). Resistin did not correlate with age $(r=-0.08, P=0.24)$, but correlated positively with BMI $(r=0.60, P<0.001)$. Adiponectin, leptin, and resistin were not associated with smoking, obesity, sex, and medications.

Based on the continuity equation, 32 patients had severe, 21 moderate, and 21 mild AS (TABLE 2). Patients with severe AS were younger than those with with mild/moderate AS $(53.3 \pm 6.1$ vs. 61.7 \pm 9.4 years, $P<0.001)$. Adiponectin correlated positively with the AVAI $(r=0.70, P<0.001)$ and inversely with the mean PG $(r=-0.72, P<0.001)$ and peak PG $(r=-0.67, P<0.001)$. Leptin correlated positively with the AVAI $(r=0.37, P=0.001)$, and inversely with the mean PG $(r=-0.27, P=$ $0.009)$ and peak $P G(r=-0.23, P=0.03)$. No correlations were observed between resistin and the above variables $(P>0.1)$.

After adjusting for age and BMI, adiponectin levels differed depending on the severity of AS, with the highest values in patients with mild AS $(26.7 \pm 0.9 \mu \mathrm{g} / \mathrm{ml})$, lower in moderate AS $(20.2 \pm 0.9 \mu \mathrm{g} / \mathrm{ml})$, and the lowest in severe AS $(17.5 \pm 0.7 \mu \mathrm{g} / \mathrm{ml})(P<0.001)$. The post-hoc Sidak corrected comparison showed that patients with mild AS had higher adiponectin adjusted for age and BMI that those with moderate $(P=0.001)$ or severe AS $(P<0.001)$. Compared with controls, adiponectin adjusted for age and BMI was higher in mild AS, but lower in severe AS (both $P<0.001)$. No difference in adiponectin was observed between subjects with moderate AS and controls (FIGURE 2).

After adjusting for age and BMI, leptin tended to decrease with increasing severity of AS mild AS $(21.1 \pm 1.3 \mathrm{ng} / \mathrm{ml})$, moderate AS (16.9 $\pm 1.3 \mathrm{ng} / \mathrm{ml})$, and severe AS $(14.4 \pm 1.1 \mathrm{ng} / \mathrm{ml})$ $(P=0.003)$. Leptin adjusted for age and BMI was 


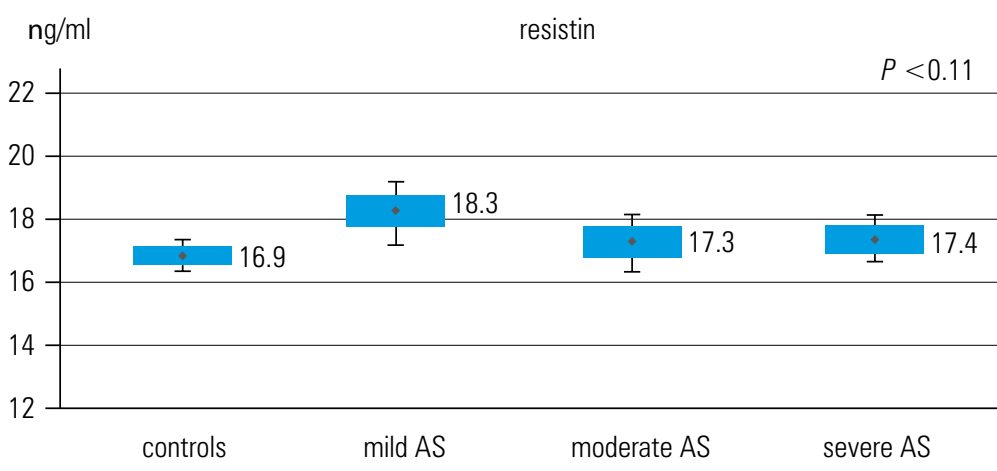

FIGURE 4 Plasma levels of resistin in patients with aortic stenosis and in controls; values are shown as mean $\pm \mathrm{SD}$ and $95 \% \mathrm{Cl}$

Abbreviations: see TABLE 1 and FIgURE 1 lower in severe than in mild AS $(P=0.001)$. Compared with controls, subjects with mild AS had higher leptin levels $(P=0.02)$. No difference in leptin levels was observed between controls and patients with moderate and severe AS (FIGURE 3).

After adjustment for age and BMI, no differences in resistin levels were observed between the subjects with mild, moderate, and severe AS $(18.3 \pm 0.5 \mathrm{ng} / \mathrm{ml}, 17.3 \pm 0.5 \mathrm{ng} / \mathrm{ml}$, and 17.4 $\pm 0.4 \mathrm{ng} / \mathrm{ml}$, respectively, $P=0.11$; FIgURe 4).

Predictors of severe aortic stenosis In regression analysis models, after adjusting for potential confounding factors including age and BMI, the mean PG was the only independent echocardiographic predictor of adiponectin $\left(\Delta \mathrm{R}^{2}=0.08\right.$, $P<0.001$ ), while the AVAI was the only independent echocardiographic predictor of leptin $\left(\Delta \mathrm{R}^{2}=0.04, P=0.049\right)$ in patients with AS (TABle 3). No echocardiographic parameters predicted resistin levels in patients with AS.
The following parameters were associated with severe AS in a univariable logistic regression analysis: age (OR 0.88; 95\% CI 0.82-0.94, $P<0.001)$, low-density lipoprotein cholesterol (OR 0.56; 95\% CI 0.33-0.95, $P=0.03$ ), total cholesterol (OR 0.59; 95\% CI 0.38-0.93, $P=0.02$ ), bicuspid aortic valve (OR 3.4; 95\% CI 1.02-11.2, $P=0.047$ ), thickness of interventricular septum (OR 2.89; 95\% CI 1.63-5.13, $P<0.001$ ), thickness of LV posterior wall (OR 1.61, 95\% CI 1.16-2.24, $P$ $=0.004$ ), adiponectin (OR 0.75; 95\% CI 0.64-0.89, $P=0.001$ ), and leptin (OR 0.89; 95\% CI 0.82-0.97, $P=0.01)$. In a multivariable analysis, only adiponectin (OR $0.74 ; 95 \%$ CI $0.62-0.88, P=0.001$ ) and total cholesterol (OR 0.58; 95\% CI 0.36-0.94, $P=0.03$ ) were independently associated with severe AS (TABLE 4).

DISCUSSION The main finding of the current study is that plasma adiponectin and leptin levels are associated with AS severity. Mean PG is an independent predictor of adiponectin levels, while the AVAI predicts leptin levels in patients with AS. Our findings expand our knowledge on the links between adipocytokines and cardiac diseases, showing for the first time that AS might be to some extent modulated by adipocytokine profile in circulating blood, with a major role of adiponectin. We have shown that patients with severe AS have lower adiponectin levels compared with those with moderate and mild AS.

Subjects with atherosclerotic vascular disease were excluded from our study. This suggests that the association between adiponectin levels and AS is independent of coronary artery disease. Given the accumulating evidence for similarity be tween the pathogenesis of atherosclerosis and AS, our results have reinforced the available data on a protective role of adiponectin in cardiovascular

TAB LE 3 Multiple regression analysis: the incremental value of echocardiographic variables in the prediction of plasma adiponectin and leptin levels in patients with aortic stenosis

\begin{tabular}{|c|c|c|c|c|c|c|}
\hline & & b & $b_{S E}$ & $\beta$ & $P$ & $\mathrm{R}^{2}$ \\
\hline \multirow{7}{*}{ adiponectin } & step 1 & & & & & \\
\hline & age & 0.61 & 0.06 & 0.70 & $<0.001$ & 0.70 \\
\hline & BMI & -0.58 & 0.16 & -0.26 & $<0.001$ & \\
\hline & step 2 & & & & & \\
\hline & age & 0.46 & 0.06 & 0.53 & $<0.001$ & $0.78^{\mathrm{a}}$ \\
\hline & BMI & -0.46 & 0.14 & -0.21 & 0.001 & \\
\hline & mean pressure gradient & -0.14 & 0.03 & -0.34 & $<0.001$ & \\
\hline \multirow{7}{*}{ leptin } & step 1 & & & & & \\
\hline & age & 0.15 & 0.08 & 0.21 & 0.08 & 0.18 \\
\hline & BMI & -0.53 & 0.21 & -0.29 & 0.02 & \\
\hline & step 2 & & & & & \\
\hline & age & 0.04 & 0.10 & 0.05 & 0.70 & $0.22^{\mathrm{a}}$ \\
\hline & BMI & -0.51 & 0.21 & -0.28 & 0.02 & \\
\hline & AVAl & 5.51 & 2.75 & 0.27 & 0.049 & \\
\hline
\end{tabular}


TABLE 4 Association of clinical, laboratory, and echocardiographic parameters with severe aortic stenosis

\begin{tabular}{|c|c|c|c|c|}
\hline & \multicolumn{2}{|c|}{ Univariable } & \multicolumn{2}{|c|}{ Multivariable } \\
\hline & OR (95\% Cl) & $P$ & OR (95\% CI) & $P$ \\
\hline \multicolumn{5}{|l|}{ clinical data } \\
\hline male sex & $2.16(0.67-6.93)$ & 0.20 & & \\
\hline age, y & $0.88(0.82-0.94)$ & $<0.001$ & & \\
\hline $\mathrm{BMI}, \mathrm{kg} / \mathrm{m}^{2}$ & $1.1(0.96-1.26)$ & 0.16 & & \\
\hline smoking & $1.01(0.39-2.57)$ & 0.99 & & \\
\hline hypertension & $1.82(0.69-4.76)$ & 0.22 & & \\
\hline hypercholesterolemia & $0.22(0.04-1.16)$ & 0.07 & & \\
\hline \multicolumn{5}{|l|}{ laboratory tests } \\
\hline fasting glucose, $\mathrm{mmol} / \mathrm{l}$ & $1.49(0.71-3.12)$ & 0.29 & & \\
\hline $\mathrm{TC}, \mathrm{mmol} / \mathrm{l}$ & $0.59(0.38-0.93)$ & 0.02 & $0.58(0.36-9.34)$ & 0.03 \\
\hline LDL-C, mmol/l & $0.56(0.33-0.95)$ & 0.03 & & \\
\hline HDL-C, mmol/l & $0.68(0.12-3.89)$ & 0.67 & & \\
\hline $\mathrm{TG}, \mathrm{mmol} / \mathrm{l}$ & $1.01(0.62-1.66)$ & 0.97 & & \\
\hline creatinine, $\mu \mathrm{mol} / \mathrm{l}$ & $0.97(0.93-1.0)$ & 0.08 & & \\
\hline hsCRP, mg/l & $0.85(0.67-1.09)$ & 0.20 & & \\
\hline fibrinogen, $g / l$ & $0.96(0.67-1.38)$ & 0.83 & & \\
\hline adiponectin, $\mu \mathrm{g} / \mathrm{ml}$ & $0.75(0.64-0.89)$ & 0.001 & $0.74(0.62-0.88)$ & 0.001 \\
\hline resistin, ng/ml & $1.03(0.88-1.21)$ & 0.74 & & \\
\hline leptin, ng/ml & $0.89(0.82-0.97)$ & 0.01 & & \\
\hline \multicolumn{5}{|l|}{ echocardiographic variables } \\
\hline LVEF, \% & $1.05(0.99-1.11)$ & 0.13 & & \\
\hline LVEDV index, ml/m² & $0.99(0.96-1.01)$ & 0.31 & & \\
\hline bicuspid aortic valve & $3.4(1.02-11.2)$ & 0.047 & & \\
\hline interventricular septum, mm & $2.89(1.63-5.13)$ & $<0.001$ & & \\
\hline posterior wall, mm & $1.61(1.16-2.24)$ & 0.004 & & \\
\hline \multicolumn{5}{|l|}{ medications } \\
\hline$\beta$-blockers & $0.5(0.19-1.28)$ & 0.15 & & \\
\hline ACEI & $0.66(0.25-1.72)$ & 0.39 & & \\
\hline ARB & $0.68(0.31-5.9)$ & 0.68 & & \\
\hline calcium blockers & $0.98(0.35-2.72)$ & 0.97 & & \\
\hline diuretics & $0.79(0.27-2.33)$ & 0.67 & & \\
\hline ASA & $0.62(0.14-2.70)$ & 0.53 & & \\
\hline statins & $1.26(0.50-3.22)$ & 0.62 & & \\
\hline
\end{tabular}

Abbreviations: ACEI - angiotensin-converting enzyme inhibitors, ARB - angiotensin II receptor blockers, ASA acetylsalicylic acid, OR - odds ratio, others - see TABLE 1, TABLE 2, and FIGURE 1

inflammatory disorders. Hypoadiponectinemia is associated with an increased risk of coronary artery disease and higher carotid intima-media thickness. ${ }^{11}$ Moreover, it predicts the severity, extent, and pattern of atherosclerosis in coronary arteries. ${ }^{23}$

To our knowledge, there has been only 1 study, by Mohty et al., ${ }^{24}$ showing that lower adiponectin levels are associated with inflammation and calcification in AS. ${ }^{24}$ However, we did not obtain similar results. ${ }^{24}$ Differences in adiponectin levels may result from the use of different methods to determine this parameter. Mohty et al. ${ }^{24}$ used an enzyme-linked immunosorbent assay, while we applied the recently introduced method based on the Bio-Rad Luminex system. Our results obtained in the control group were similar to those reported in another study that also used this method. ${ }^{25}$ Moreover, we excluded patients with coronary artery disease and type 2 diabetes, which significantly affected adiponectin levels.

Reduced valve area in AS causes LV overload. Similar phenomenon can be observed in arterial hypertension and hypertrophic cardiomyopathy, especially with outflow obstruction. In arterial hypertension, the blood pressure increase and myocardial hypertrophy were shown to be associated with lower adiponectin levels. ${ }^{26}$ It can be assumed that, similarly to hypertensive patients, reduced adiponectin levels linked to increased severity of AS might predispose to LV hypertrophy 
and diastolic dysfunction. In healthy and obese subjects, adiponectin also inversely correlated with LV hypertrophy. ${ }^{27}$ In patients with hypertrophic cardiomyopathy, adiponectin levels also showed inverse correlations with the maximum $\mathrm{LV}$ wall thickness, but in the subgroup of patients with systolic dysfunction, a positive relationship was observed. ${ }^{28}$

It is unclear whether adiponectin is directly involved in the pathogenesis of AS, or is an indicator of stenosis, or reflects the adaptive responses. Given a prognostic value of adiponectin in cardiac hypertrophy, systolic and diastolic dysfunction, and severity of atherosclerosis in the coronary arteries, serum adiponectin levels in patients with significant AS could represent a valuable parameter in further therapeutic decisions.

In the current study, we observed increased adiponectin levels only in subjects with mild AS. Given its anti-inflammatory, antiatherosclerotic, and cardioprotective effect, it might be expected that adiponectin increases with the severity of AS. It is possible that adiponectin has a protective role in the development of AS at its early stage. Increased consumption of circulating adiponectin may reduce its plasma levels, which can limit its inhibitory effect on endothelial expression of adhesion molecules, macrophage transformation, and differentiation of vascular smooth muscle cell towards osteoblasts, resulting in the progression of inflammation and calcification of valve leaflets.

In the present study, elevated levels of leptin in the group with mild AS progressively decreased with increasing stenosis. Our results are inconsistent with those of Glader et al., ${ }^{29}$ who reported hyperleptinemia in patients with severe AS. There may be several reasons for this inconsistency. First, in contrast to our study, Glader et al. ${ }^{29}$ enrolled patients with coronary artery disease, peripheral atherosclerosis, and diabetes. Prior reports showed that these disorders are associated with increased leptin levels. Second, we enrolled younger subjects than Glader et al. ${ }^{29}$ Mohty et al. ${ }^{22}$ demonstrated that in patients with severe AS, leptin levels were higher in elderly patients ( $>70$ years) compared with middle-aged subjects. Third, we have studied patients with different severity of AS. Indeed, leptin levels were increased in those with mild AS compared with those with severe AS. It might partly result from the fact that patients with severe AS were younger. In consequence, the role of leptin in the pathogenesis and progression of AS remains elusive and further studies are needed to clarify the issue.

Our study has several limitations. First, the size of the study population was small, particularly in a subgroup analysis. Our findings possibly cannot be extrapolated to AS patients with reduced EF, coronary artery disease, type 2 diabetes, and atrial fibrillation, because they were excluded from the study. Second, mean age was relatively low compared with the epidemiological data on
AS prevalence; this could be partly due to the inclusion of patients with both tricuspid and bicuspid aortic valve stenosis. Third, no measurements were performed following valve replacement; therefore, it is unclear whether decreased adiponectin and leptin levels in severe AS are reversible.

In conclusion, the main finding of our study is that plasma adiponectin and leptin levels are associated with AS severity. Presumably, adiponectin and leptin are involved in the development and progression of AS. It might be speculated that adiponectin plays a protective role in this process and lower adiponectin levels may predispose to severe AS. A larger study on patients with mild AS and a long follow-up are needed to assess clinical relevance of the present findings.

Acknowledgments We thank Professor Anetta Undas for helpful comments in the preparation of this manuscript. The study has been supported by a grant of the Polish Ministry of Science and Higher Education (No. N402 383338).

\section{REFERENCES}

1 Natorska J, Marek G, Hlawaty M, et al. Evidence for tissue factor ex pression in aortic valves in patients with aortic stenosis. Pol Arch Med Wewn. 2009; 119: 636-643.

2 O'Brien KD. Pathogenesis of calcific aortic valve disease: a disease process comes of age (and a good deal more). Arterioscler Thromb Vasc Biol. 2006; 26: 1721-1728.

3 Galic S, Oakhill JS, Steinberg GR. Adipose tissue as an endocrine organ. Mol Cell Endocrinol. 2010; 316: 129-139.

4 Zhang $\mathrm{H}$, Zhang $\mathrm{C}$. Regulation of microvascular function by adipose tissue in obesity and type 2 diabetes: evidence of an adipose-vascular loop. Am J Biomed Sci. 2009; 1: 133-142.

5 Adamczak M, Rzepka E, Chudek J, Więcek A. Ageing and plasma adiponectin concentration in apparently healthy males and females. Clinical Endocrinol (0xf). 2005; 62: 114-118.

6 Bettowski J, Jamroz-Wiśniewska A, Widomska S. Adiponectin and its role in cardiovascular diseases. Cardiovasc Hematol Disord Drug Targets 2008; 8: 7-46.

7 Holecki M, Wiecek A. Relationship between body fat mass and bone metabolism. Pol Arch Med Wewn. 2010; 120: 361-367.

8 Shibata R, Ouchi N, Ito M, et al. Adiponectin-mediated modulation of hypertrophic signals in the heart. Nat Med. 2004; 10: 1384-1389.

9 Hattori $Y$, Hattori S, Akimoto $K$, et al. Globular adiponectin activates nuclear factor-kappaB and activating protein-1 and enhances angiotensin II-induced proliferation in cardiac fibroblasts. Diabetes. 2007; 56: 804-808.

10 Luo XH, Zhao LL, Yuan LQ, et al. Development of arterial calcification in adiponectin-deficient mice: adiponectin regulates arterial calcification J Bone Miner Res. 2009; 24: 1461-1468.

11 Abiko A, Makita S, Naganuma Y, et al. Association between metabolic syndrome and carotid atherosclerosis: relevance of combined criteria in cluding the serum adiponectin level for the general population. Intern Med. 2011; 50: 381-387.

12 Gualillo 0, González-Juanatey JR, Lago F. The emerging role of adipokines as mediators of cardiovascular function: physiologic and clinical perspectives. Trends Cardiovasc Med. 2007; 17: 275-283.

13 Asferg C, Møgelvang R, Flyvbjerg A, et al. Leptin, not adiponectin, predicts hypertension in the Copenhagen City Heart Study. Am J Hypertens 2010; 23: 327-333

14 Taneli F, Yegane S, Ulman C, et al. Increased serum leptin concentrations in patients with chronic stable angina pectoris and ST-elevated myo cardial infarction. Angiology. 2006; 57: 267-272.

15 Lembo G, Vecchione C, Fratta L, et al. Leptin induces direct vasodilation through distinct endothelial mechanisms. Diabetes. 2000; 49: 293-297.

16 Rajapurohitam V, Javadov S, Purdham DM, et al. An autocrine role for leptin in mediating the cardiomyocyte hypertrophic effects of angiotensin II and endothelin-1. J Mol Cell Cardiol. 2006; 41: 265-274.

17 Dong F, Zhang X, Ren J. Leptin regulates cardiomyocyte contrac tile function through endothelin-1 receptor-NADPH oxidase pathway Hypertension. 2006; 47: 222-229. 
18 Lee $Y$, Naseem RH, Duplomb L, et al. Hyperleptinemia prevents lipotoxic cardiomyopathy in acyl CoA synthase transgenic mice. Proc Natl Acad Sci U S A. 2004; 101: 13624-13629.

19 Smith CC, Mocanu MM, Davidson SM, et al. Leptin, the obesity-associated hormone, exhibits direct cardioprotective effects. $\mathrm{Br}$ J Pharmacol. 2006; 149: 5-13.

20 Trujillo ME, Scherer PE. Adipose tissue-derived factors: impact on health and disease. Endocr Rev. 2006; 27: 762-778.

21 Reilly MP, Lehrke M, Wolfe ML, et al. Resistin is an inflammatory mark er of atherosclerosis in humans. Circulation. 2005; 111: 932-939.

22 Mohty $D$, Pibarot $P$, Després JP, et al. Age-related differences in the pathogenesis of calcific aortic stenosis: the potential role of resistin. Int J Cardiol. 2010; 142: 126-132.

23 Hasan-Ali H, Abd El-Mottaleb NA, Hamed HB, Abd-Elsayed A. Serum adiponectin and leptin as predictors of the presence and degree of coronary atherosclerosis. Coron Artery Dis. 2011; 22: 264-269.

24 Mohty $\mathrm{D}$, Pibarot $\mathrm{P}$, Côté $\mathrm{N}$, et al. Hypoadiponectinemia is associated with valvular inflammation and faster disease progression in patients with aortic stenosis. Cardiology. 2011; 118: 140-146.

25 Allison MA, Cushman M, Callas PW, et al. Adipokines are associated with lower extremity venous disease: the San Diego population study. J Thromb Haemost. 2010; 8: 1912-1918.

26 Hong SJ, Park CG, Seo HS, et al. Associations among plasma adiponectin, hypertension, left ventricular diastolic function and left ventricular mass index. Blood Press. 2004; 13: 236-242.

27 Ebinç H, Ebinç FA, Ozkurt ZN, et al. Impact of adiponectin on left ventricular mass index in non-complicated obese subjects. Endocr J. 2008; 55 . 523-528.

28 Kitaoka H, Kubo T, Okawa M, et al. Plasma adiponectin levels and left ventricular remodeling in hypertrophic cardiomyopathy. Int Heart J. 2010; 51: $51-55$

29 Glader CA, Birgander LS, Söderberg S, et al. Lipoprotein(a), Chlamydia pneumoniae, leptin and tissue plasminogen activator as risk markers for valvular aortic stenosis. Eur Heart J. 2003; 24: 198-208. 


\title{
Adiponektyna, leptyna i rezystyna u chorych ze stenozą aortalną bez towarzyszącej miażdżycy naczyń
}

\author{
Renata Kolasa-Trela', Tomasz Miszalski-Jamka', \\ Grzegorz Grudzieńn ${ }^{1,2}$, Ewa Wypasek ${ }^{1,2}$, Magdalena Kostkiewicz ${ }^{1,2}$ \\ 1 Krakowski Szpital Specjalistyczny im. Jana Pawła II, Kraków \\ 2 Instytut Kardiologii, Uniwersytet Jagielloński, Collegium Medicum, Kraków
}

\section{SŁOWA KLUCZOWE}

adipocytokiny, adiponektyna, leptyna, rezystyna, stenoza aortalna
Adres do korespondencji: dr hab. med. Magdalena Kostkiewicz, Instytut Kardiologii, Uniwersytet Jagielloński, Collegium Medicum, ul. Prądnicka 80, 31-202 Kraków, tel.: 12-614-35-14, fax: 12-614-25-26, e-mail: mkostkiewicz@szpitaljp2. krakow.pl

Praca wpłynęła: 02.09.2011. Przyjęta do druku: 23.09.2011 Nie zgłoszono sprzeczności interesów.

Pol Arch Med Wewn. 2011; 121 (10): 352-360

Copyright by Medycyna Praktyczna, Kraków 2011

\section{STRESZCZENIE}

WPROWADZENIE Wczesne stadia miażdżycy i stenozy aortalnej (aortic stenosis - AS) są podobne. Zaawansowana choroba wieńcowa charakteryzuje się zmienionym profilem krążących we krwi adipocytokin. Wysunęliśmy hipotezę, że osoczowy profil adipocytokin wiąże się z ciężkością AS.

CELE Celem pracy była ocena związku pomiędzy AS a adipocytokinami.

PACJENCI I METODY U 74 chorych z AS, bez towarzyszącej miażdżycy oraz z frakcją wyrzutową $>50 \%$ (57 mężczyzn, 17 kobiet, wiek $58 \pm 9,1$ lat), i u 74 osób z grupy kontrolnej oznaczono w osoczu poziom rezystyny, leptyny i adiponektyny metodą Bio-Rad Luminex. W badaniu echokardiograficznym mierzono powierzchnię zastawki aortalnej z indeksacją do powierzchni ciała (aortic valve area indexed to body surface area - AVAI) oraz średniego i maksymalnego gradientu przezzastawkowego (pressure gradient - PG).

WYNIKI Obserwowano podobny poziom adiponektyny i leptyny u pacjentów z AS i w grupie kontrolnej (odpowiednio 20,8 \pm 7,9 vs 20,4 $\pm 3,9 \mu \mathrm{g} / \mathrm{ml} ; \mathrm{p}=0,67$ i 17,0 $\pm 6,4$ vs $16,4 \pm 5,9 \mathrm{ng} / \mathrm{ml} ; \mathrm{p}=0,52$ ). U 21 pacjentów stwierdzono łagodną AS, u 21 - umiarkowaną, a u 32 - ciężką. Po uwzględnieniu wieku i wskaźnika masy ciała poziom adiponektyny wynosił 20,3 $\pm 0,5 \mu \mathrm{g} / \mathrm{ml}$ w grupie kontrolnej oraz $26,7 \pm 0,9 \mu \mathrm{g} / \mathrm{ml}$ w grupie łagodnej AS, 20,2 $\pm 0,9 \mu \mathrm{g} / \mathrm{ml}$ w grupie umiarkowanej AS i 17,5 $\pm 0,7 \mu \mathrm{g} / \mathrm{ml}$ w grupie ciężkiej AS ( $\mathrm{p}<0,001$ ). Poziom leptyny wynosił $16,4 \pm 0,7 \mathrm{ng} / \mathrm{ml}$ w grupie kontrolnej oraz $21,1 \pm 1,3 \mathrm{ng} / \mathrm{ml}$ w grupie łagodnej, 16,9 $\pm 1,3 \mathrm{ng} / \mathrm{ml}$ w grupie umiarkowanej i 14,4 $\pm 1,1 \mathrm{ng} / \mathrm{ml}$ w grupie ciężkiej AS ( $\mathrm{p}=0,003)$. Adiponektyna i leptyna korelowały z AVAI (odpowiednio $r=0,70, p<0,001$ i $r=0,37, p=0,001$ ), średnim PG (odpowiednio $r=-0,72, p<0,001$ i $r=-0,27, p=0,009$ ) i maksymalnym PG (odpowiednio $r=-0,67, p<0,001$ i $r=-0,23, p=0,03$ ). W analizie wieloczynnikowej średni PG był jedynym niezależnym echokardiograficznym predyktorem poziomu adiponektyny ( $p<0,001$ ), natomiast AVAI była jedynym niezależnym echokardiograficznym predyktorem poziomu leptyny w surowicy u chorych z AS ( $p=0,049)$.

WNIOSKI Obniżony poziom adiponektyny i leptyny, ale nie rezystyny, wiąże się z ciężką AS, co sugeruje, że adipocytokiny mogą uczestniczyć w progresji AS, szczególnie adiponektyna pełniąca w tym procesie rolę ochronną. 